\title{
Smart Walking Cane For Blind
}

\author{
F. Emerson Solomon, S.Prasath, T.Manoj Prasath, R.Vasuki
}

\begin{abstract}
A Smart visually impaired strolling stick is an advancement of stick intended for the utilization of outwardly handicapped individuals for recognizing the route and impediment before them. We have proposed here a propelled visually impaired strolling stick that permits the outwardly tested individuals for strolling and to explore simple through voice playback utilizing cutting edge innovation. The visually impaired strolling stick is presented with ultrasonic sensors. The target of our venture is to give the outwardly disabled to better navigational device. First utilization of ultrasonic sensors to recognize hindrances ahead utilizing ultrasonic waves makes object recognition simpler. On detecting the hindrance, the sensor passes this information to microcontroller. At that point, the microcontroller procedure this information and ascertains, If the impediment is before it raises the vibration and utilizing voice playback to help. This helps the outwardly provoked individual to explore uninhibitedly. The vibration associated with the stick is utilized for the sign of obstruction. Our framework has one propelled highlight that is the voice playback framework to explore unreservedly.
\end{abstract}

Keywords: Microcontroller, Vibrator engine, Ultrasonic Sensor, Voice playback, Walking stick.

\section{INTRODUCTION}

There are 37 million approx. individuals, over the globe who are visually impaired, more than 15 million are from India. People have vision shortcoming are consistently dependent and require an outside help or an individual to control them for their course. The most basic and customary contraption for the people which investigates them is the standard white stick. Hence, in this paper we have changed the walking stick, since outwardly disabled people are simply prepared to separate the closeness of any articles either by a touch or by a stick. The customer clears the stick forward and in reverse before them and on hitting any of the things moreover if with the stair case the customer winds up doubtlessly aware of the tangle, we have proposed the system such that we structure a circuit which comprise of Ultrasonic sensor fitted them at the appropriate position on a stick to such an extent that they effectively can give.

Revised Manuscript Received on July 10, 2019.

Dr. F. Emerson Solomon, Associate Professor, Department of Biomedical Engineering, Bharath Institute of Higher Education and Research, Chennai-600073. T.N, India

S. Prasath, Associate Professor, Department of Biomedical Engineering, Bharath Institute of Higher Education and Research, Chennai600073. T.N, India

T. Manoj Prasath, Associate Professor, Department of Biomedical Engineering, Bharath Institute of Higher Education and Research, Chennai600073. T.N, India

Dr. R. Vasuki, Associate Professor, Department of Biomedical Engineering, Bharath Institute of Higher Education and Research, Chennai600073. T.N, India

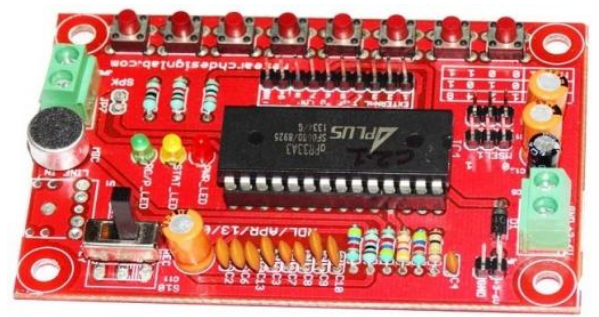

Figure 1. A Voice Playback Module

Data in the surroundings through a sound criticism [1-6].

This framework has been included with voice playback module which can be utilized to explore while the articles come in front. This gadget is anything but difficult to utilize and it has a battery-powered battery of $12 \mathrm{~V}$. This is a model is effective and needs a low support and can be effectively reasonable [7-11].

\section{MATERIALS AND METHODOLOGY}

The fundamental structure of this module depends on sensor that is Ultrasonic sensor which are coordinated on a solitary circuit board and interfaced with a small scale controller which has implanted c programming as principle utilitarian instrument and voice playback framework[17-21].

\section{A Embedded c}

The Prototype is made with an embedded c programming which is changed inside a scaled down scale controller (ATMEGA328) that is fabricated on a circuit load up which is a 8-bit processor in light of an AVR distinctive plan which shapes in a lone time throughput of 20MIPS at the rate of $20 \mathrm{mhz}$, this processor. The composition PC programs is coded in that limit depending upon the condition if the obstacle is far away from the stick it frames by learning the partition and if its closer to the subject it will give the condition to raise the alert and the preventive measure can be taken in like way, the detachment can be adjusted alluringly on the circuit board [12-16].

\section{B Ultrasonic sensor}

This module involves different sensors. A Ultrasonic sensor is used as a piece of the contraption which is fitted at the front some segment of the device; the basic guideline for this method is Doppler Effect since we can change the repeat of the sensor [22-29].

The ultrasonic sensor is a device that estimates a detachment from the transmitting end and the hindrance it recalls the method for transmission and thusly engages to distinguish the dissent evacuate, this standard is uses a comparable miracle to perceive the obstacles on humbler partition and along these lines it empower the person to

\section{Published By:}

Blue Eyes Intelligence Engineering

\& Sciences Publication

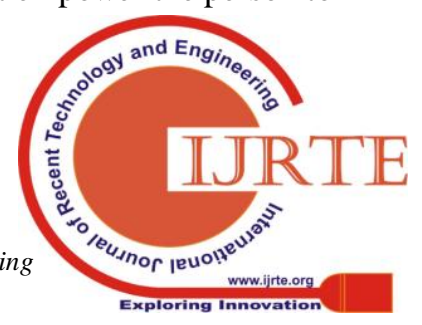


explore effectively without meeting any effect [30-35].

\section{Voice playback module}

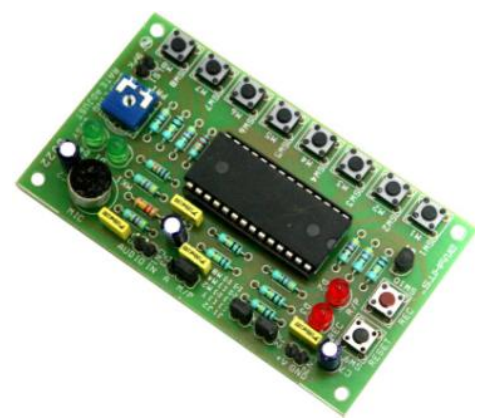

This module is put inside and the out is given out through the earphones. Playback devices are fused circuits that partner with collectors and speakers, or the upgrade circuits related with intensifiers and speakers. They engage set away solid examples as inspected data to be changed over to basic banners and respect a speaker or related enhancer for playback purposes. It gives extraordinary chronicle and playback with 11 Minutes sound at $8 \mathrm{Khz}$ Sampling rate with 16 bit assurance. The aPR33A game plan C2.x is astoundingly planned for essential key trigger, customer can record and playback the message averagely for $1,2,4$ or 8 voice message(s) by switch, It is sensible in clear interface or need to confine the length of single message [43-45].

\section{RESULT AND DISCUSSION}

This is gadget straightforward and practical and has a basic technique to help the outwardly tested individual, it is anything but difficult to deal with and use as a versatile gadget. A reset catch is added to the framework. The whole contraption is proposed to be nearly nothing and is used as a piece of combination with the stick. The ultrasonic sensor wears down Doppler Effect. This comprises of a Ultrasonic transmitter and a recipient which is utilized to identify in some separation. In addition it comprise of a voice playback improved route for the outwardly tested individual [36-42].

\section{FUTURE WORK AND CONCLUSION}

In future, the movements that can be made is to incorporate the more common sensors so as do alarm even more suitably. More use should be conceivable by taking after certain framework parameters of the framework which are taking after:

- Detection of ground level snag

- Color acknowledgment

- GPS route framework.

\section{REFERENCES}

1. Sharmila S., Jeyanthi Rebecca L., Das M.P.,Production of Biodiesel from Chaetomorpha antennina and Gracilaria corticata,Journal of Chemical and Pharmaceutical Research,V-4,I-11,PP-4870-4874,Y-2012

2. Aarthi C., Ramesh Babu P.B.,Anti-cancer activity of Phyllanthus reticulatus on colon cancer cell line, International Journal of Civil Engineering and Technology, V-8,I-1,PP-943947,Y-2017 module to the gadget to have additional element for the

3. Sharmila S., Jeyanthi Rebecca L., Das M.P., Saduzzaman M.,Isolation and partial purification of protease from plant leaves,Journal of Chemical and Pharmaceutical Research, V4,I-8,PP-3808-3812,Y-2012

4. Jayalakshmi T., Krishnamoorthy P., Ramesh Babu P.B., Vidhya B.,Production, purification and Biochemical characterization of alkaline Fibrinolytic enzyme from Bacillus subtilisstrain-GBRC1,Journal of Chemical and Pharmaceutical Research,V-4,I-12,PP-5027-5031,Y-2012

5. Jeyanthi Rebecca L., Susithra G., Sharmila S., Das M.P.,Isolation and screening of chitinase producing Serratia marcescens from soil,Journal of Chemical and Pharmaceutical Research,V-5,I-2,PP-192-195,Y-2013

6. Aarthi C., Ramesh Babu P.B.,Antimicrobial and antioxidant activity of phyllanthus niruri,International Journal of Pharmacy and Technology,V-8,I-2,PP-14701-14707,Y-2016

7. Anbuselvi S., Jeyanthi Rebecca L., Sathish Kumar M., Senthilvelan T.,GC-MS study of phytochemicals in black gram using two different organic manures, Journal of Chemical and Pharmaceutical Research,V-4,I-2,PP-12461250,Y-2012

8. Soniyapriyadharishni A.K., Ramesh Babu P.B.,Data mining strategies for identification of HNF4A MODY gene using gene prioritize tool,Journal of Chemical and Pharmaceutical Research,V-6,I-3,PP-1126-1133,Y-2014

9. Sharmila S., Jeyanthi Rebecca L., Naveen Chandran P., Kowsalya E., Dutta H., Ray S., Kripanand N.R.,Extraction of biofuel from seaweed and analyse its engine performance,International Journal of Pharmacy and Technology,V-7,I-2,PP-8870-8875,Y-2015

10. Sharmila S., Jeyanthi Rebecca L., Saduzzaman M.,Biodegradation of domestic effluent using different solvent extracts of Murraya koenigii,Journal of Chemical and Pharmaceutical Research,V-5,I-2,PP-279-282,Y-2013

11. Jeyanthi Rebecca L., Sharmila S., Das M.P., Seshiah C., Extraction and purification of carotenoids from vegetables,Journal of Chemical and Pharmaceutical Research,V-6,I-4,PP-594-598,Y-2014

12. Krishnamoorthy P., Praveen Kumar P.K., Ramesh Babu P.B.,Community based evaluation of phenylthiocarbamide (PTC) sensitivity and Dermatoglyphics as a genetic marker in Tamilnadu, India,International Journal of Pharmacy and Technology, V-5,I-3,PP-5705-5712,Y-2013

13. Sharmila S., Jeyanthi Rebecca L.,GC-MS Analysis of esters of fatty acid present in biodiesel produced from Cladophora vagabunda,Journal of Chemical and Pharmaceutical Research,V-4,I-11,PP-4883-4887,Y-2012

14. Sinha S., Rajasulochana P., Ramesh Babu P.B., Krishnamoorthy P.,Comparative modelling of shikimate kinase $(\mathrm{M} \mathrm{Tb})$ and molecular docking studies of its known inhibitors, Research Journal of Pharmaceutical, Biological and Chemical Sciences, V-4,I-3,PP-715-720,Y-2013

15. Jeyanthi Rebecca L., Dhanalakshmi V., Sharmila S.,Effect of the extract of Ulva sp on pathogenic microorganisms,Journal of Chemical and Pharmaceutical Research,V-4,I-11,PP-4875$4878, Y-2012$

16. Sharmila S., Jeyanthi Rebecca J.,A comparative study on the degradation of leather industry effluent by Marine algae,International Journal of Pharmaceutical Sciences Review and Research,V-25,I-2,PP-46-50,Y-2014

17. Ramesh Babu P.B., Krishnamoorthy P., Gayathri G.,Identification of drug target site on citrate synthase of food pathogen - Campylobacter jejuni,Research Journal of Pharmaceutical, Biological and Chemical Sciences, V-4,I1,PP-618-623,Y-2013 
18. Sharmila S., Rebecca Jeyanthi L., Saduzzaman M.,Biodegradation of tannery effluent using Prosopis juliflora,International Journal of ChemTech Research,V-5,I-5, PP-2186-2192,Y-2013

19. Kumar S., Das M.P., Jeyanthi Rebecca L., Sharmila S.,Isolation and identification of LDPE degrading fungi from municipal solid waste,Journal of Chemical and Pharmaceutical Research,V-5,I-3,PP-78-81,Y-2013

20. Das M.P., Jeyanthi Rebecca L., Sharmila S., Anu, Banerjee A., Kumar D.,Identification and optimization of cultural conditions for chitinase production by Bacillus amyloliquefaciens SM3,Journal of Chemical and Pharmaceutical Research,V-4,I-11,PP-4816-4821,Y-2012

21. Ramesh Babu P.B., Krishnamoorthy P., Rekha R.,Develoment of comprehensive online database model for genes responsible for asthma,Research Journal of Pharmaceutical, Biological and Chemical Sciences, V-4,I-1,PP-865-871,Y-2013

22. Devi M., Jeyanthi Rebecca L., Sumathy S.,Bactericidal activity of the lactic acid bacteria Lactobacillus delbreukii,Journal of Chemical and Pharmaceutical Research,V-5,I-2,PP-176-180,Y-2013

23. Ramesh Babu P.B., Miller T.L., Chidekel A., Shaffer T.H.,Clara cell protein mediates secretion of proteins, IL-8 and IL-6 in human airway epithelial cell line Calu-3 exposed to hyperoxia,Journal of Chemical and Pharmaceutical Research,V-4,I-6,PP-3164-3170,Y-2012

24. Bhuvaneswari B., Hari R., Vasuki R., Suguna,Antioxidant and antihepatotoxic activities of ethanolic extract of Solanum torvum,Asian Journal of Pharmaceutical and Clinical Research,V-5,I-SUPPL. 3,PP-147-150,Y-2012

25. Abraham Samuel F., Mohan V., Jeyanthi Rebecca L.,Physicochemical and heavy metal analysis of sugar mill effluent,Journal of Chemical and Pharmaceutical Research,V6,I-4,PP-585-587,Y-2014

26. Narayani P.C., Anbu J., Vasuki R., Hari R.,Invitro and invivo anti-arthritic activity of combined ethanolic extracts of Calotropis gigantea and Cardiospermum halicacabum in Wistar rats,Journal of Natural Remedies,V-14,I-1,PP-58 $66, \mathrm{Y}-2014$

27. Paul Das M., Jeyanthi Rebecca L., Sharmila S., Anu, Banerjee A., Kumar D.,Identification and optimization of cultural conditions for chitinase production by Bacillus amyloliquefaciens SM3,Journal of Chemical and Pharmaceutical Research,V-4,I-12,PP-4969-4974,Y-2012

28. Vasuki R., Hari R., Pandian S., Arumugam G.,Hepatoprotective action of ethanolic extracts of eclipta alba and piper longum linn and their combination on CCL 4 induced hepatotoxicity in rats,International Journal of Pharmacy and Pharmaceutical Sciences, V-4,I-SUPPL.1,PP455-459,Y-2012

29. Saduzaman M., Sharmila S., Jeyanthi Rebecca L.,Efficacy of leaf extract of Moringa oleifera in treating domestic effluent,Journal of Chemical and Pharmaceutical Research,V5,I-2,PP-139-143,Y-2013

30. Senthil Kumar K., Vasuki R., Priya R.,Green synthesis, pegylation of silver nano herbal complexand study of its antimutagenicity activity,International Journal of Pharmacy and Technology,V-8,I-2,PP-12130-12143,Y-2016

31. Srivastava S., Seethalakshmi I., Jeyanthi Rebecca L.,Antimicrobial and antioxidant properties of cissus quandrangularis,Journal of Chemical and Pharmaceutical Research,V-5,I-5,PP-131-134,Y-2013

32. Gireeshan M.G., Vasuki R., Krishnakumar T.,High power production from elephantâ $\hat{}^{\mathrm{TM}} \mathrm{S}$ urine,International Journal of Pharmacy and Technology,V-6,I-2,PP-6714-6718,Y-2014

33. Jeyanthi Rebecca L., Dhanalakshmi V., Sharmila S., Das M.P.,In vitro antimicrobial activity of Gracilaria SP and Enteromorpha SP,Research Journal of Pharmaceutical, Biological and Chemical Sciences, V-4,I-1, PP-693-697, Y2013
34. Jeyanthi Rebecca L., Dhanalakshmi V., Thomas T.,A comparison between the effects of three algal extracts against pathogenic bacteria,Journal of Chemical and Pharmaceutical Research,V-4,I-11,PP-4859-4863,Y-2012

35. MohdHelmyAbdWahab, Amirul A. Talib, Herdawatie A Kadir, Ayob Johari, A.Noraziah, Roslina M. Sidek, Ariffin A. "Smart cane: assistive cane for visually impairedpeople", IJCSI, Vol.8 Issue 4, July 2011

36. M. Bousbia-Salah, A. Larbi, and M. Bedda, "An approach for the measurement of distance travelled by blind and visually impaired people," in Proc. 10th IEEE Inter

37. Brabyn, J. A. (1985). A review of mobility aids and means of assessment. In D. H.Warren\&amp; E. R. Strelow (Eds.), Electronic Spatial Sensing For the Blind-ContributionsFrom Perception, Rehabilitation, and Computer Vision (pp. 13- 27). Boston, MA: MartinusNijhoff Publishers

38. Heyes, "A polaroid ultrasonic travel aid for the blind," Journal of Visual Impairment and Blindness, vol. 76, pp. 199-201, 1982.

39. ShrutiDambhare M.E 3rd SEM (ESC) G.H.R.C.E. Nagpur, Prof. A. SakhareM.Tech(ESC) G.H.R.C.E. Nagpur Smart stick for Blind: Obstacle Detection, Artificial vision and Realtime assistance via GPS.

40. Michel Mouly and Marie-Bernadette Pautet: GSM System for Mobile Communicationspublished by the authors 1992, ISBN 2-9507190- 0-7 [4] Majid Al Shamsi, Mahmoud Al- Qutayri, and Jeedella, "Blind Assistant Navigation System" in IEEE Transactions, March 2011.

41. A. R. Garcia, R. Fonseca. A. Duran. \&quot;Electronic long cane for locomotion improving on visual impaired people.\&quot; IEEE, pp.58-61, 2011.

42. G.Gayathri, M.Vishnupriya, R.Nandhini, Ms.M.Banupriya "SMART WALKING STICK FOR VISUALLY IMPAIRED" International JournalOf Engineering And ComputerScience ISSN:2319-7242 Volume 3 Issue 3 March, 2014 Page No. 4057-4061.

43. ArijitDatta "Advanced GPS \&amp; GSM Based Navigation System for Blinds" International Journal for Research in Technological Studies Vol. 1, Issue 6, May 2014 | ISSN (online):2348-1439.

44. Amit Kumar, Rusha Patra, M. Manjunatha, J. Mukhopadhyay and A. K. Majumdar an electronic travel aid for navigation of visually impaired Communication Systems andNetworks (COMSNETS), 2011 Third International conference on 4-8 jan 2011.

45. Shamsi, M.A.; Al-Qutayri, M.; Jeedella, J.; Blind assistant navigation systemBiomedical Engineering (MECBME), 2011 1st Middle East Conference on 2124 Feb. 2011

46. Michel Mouly and Marie-Bernadette Pautet: GSM System for Mobile Communications, published by the authors 1992 , ISBN 2-9507190- 0-7 [4] Majid AlShamsi,Mahmoud AlQutayri, and Jeedella, "Blind Assistant Navigation System" in IEEETransactions, March 2011. 